\title{
BIMBINGAN KELOMPOK TEKNIK OUTBOND UNTUK MENINGKATKAN KEPERCAYAAN DIRI SISWA
}

\author{
Anita Dewi Astuti \\ Program Studi Bimbingan dan Konseling \\ Fakultas Ilmu Pendidikan \\ IKIP PGRI Wates \\ E-mail: dewi_anita29@yahoo.com
}

\begin{abstract}
Abstrak
Berbagai macam faktor mempengaruhi sikap dan perilaku individu, salah satunya adalah faktor lingkungan. Seseorang yang tidak dapat menyesuaikan diri terhadap kondisi lingkungan dapat mempengaruhi rasa percaya diri. Tujuan penelitian ini adalah mengetahui efektivitas layanan bimbingan kelompok dengan teknik outbound dalam meningkatkan kepercayaan diri siswa. Metode penelitian menggunakan pendekatan kuantitatif dengan teknik pengambilan sampel dengan kombinasi antara quota sampling dan purposive sampling. Desain penelitian menggunakan control group pre-test post-test, sedangkan analisis data menggunakan t-test. Berdasarkan hasil penghitungan uji t-test maka didapat nilai thitung $=2,7$ dan nilai $t$ tabel $=1,7$ dengan demikian $t_{\text {hitung }}>t_{\text {tabel }}$ sehingga hipotesis Ho ditolak. Penolakan Ho membuktikan bahwa ada perbedaan antara rata-rata tingkat kepercayaan diri siswa dari hasil postest antara kelompok kontrol dan eksperimen sehingga layanan bimbingan kelompok dengan teknik outbound dapat dikatakan efektif untuk meningkatkan kepercayaan diri siswa.
\end{abstract}

Kata kunci: bimbingan kelompok, kepercayaan diri, outbond

\begin{abstract}
Various factors influence individual attitudes and behavior, one of which is environmental factors. A person who cannot adjust to environmental conditions can affect self-confidence. The purpose of this study was to determine the effectiveness of group guidance services with outbound techniques in increasing students' self-confidence. The research method uses a quantitative approach with sampling techniques with a combination of quota sampling and purposive sampling. The study design used a pre-test post-test control group, while the analysis used a t-test. Based on the results of the t-test test, the tcount $=2.7$ and the value of $t$ table $=1.7$ are obtained, thus $t$ count $>t$ table so that the hypothesis Ho is rejected. Ho's rejection proves that there is a difference between the average level of confidence of students from the posttest results between the control and experimental groups so that group guidance services with outbound techniques can be said to be effective in increasing student confidence.
\end{abstract}

Keywords: group guidance, confidence, outbound

Info Artikel

Diterima Oktober 2018, disetujui November 2018, diterbitkan Desember 2018 


\section{PENDAHULUAN}

Ada berbagai macam faktor yang mempengaruhi sikap dan perilaku individu, salah satunya adalah faktor lingkungan. Banyak individu yang merasa tidak bahagia karena tidak mampu menyesuaikan diri akibat perubahan lingkungan, salah satunya merasa tidak percaya diri. Rasa percaya diri seseorang sedikitnya dipengaruhi oleh dua faktor yaitu faktor internal dan faktor eksternal (Ghufron, 2010: 24). Kedua faktor tersebut menumbuhkan rasa percaya diri seseorang yang memberikan kontribusi yang besar pada penciptaan semangat, keinginan dan rasa optimisme yang besar pada manusia dalam memahami dan mencari solusi permasalahan yang dihadapinya. Kepercayaan diri yang diikuti dengan niat dan motivasi yang positif sangat berperan dalam menciptakan kemajuan aktivitas yang mengarah pada hasil yang positif bagi manusia itu sendiri.

Kepercayaan diri adalah suatu keyakinan dalam jiwa manusia bahwa tantangan hidup apapun harus dihadapi dengan berbuat sesuatu. Kepercayaan diri itu lahir dari kesadaran bahwa jika memutuskan untuk melakukan sesuatu, itu pula yang harus dilakukan. Kepercayaan diri itu akan datang dari kesadaran seorang individu bahwa individu tersebut memiliki tekad untuk melakukan apapun, sampai tujuan yang ia inginkan tercapai (Angelis, 2005 : 10). Rasa percaya diri setiap orang merupakan salah satu kekuatan jiwa yang sangat menentukan berhasil tidaknya orang tersebut dalam mencapai berbagai tujuan hidupnya.

Siswa SMP umumnya berkisar antara 12-15 tahun dimana usia tersebut menurut Havighrust (dalam Nurihsan \& Agustin, 2011: 55) berada pada tahap masa remaja. Periode ini dipandang sebagai masa rawan masalah seperti mengalami stress, frustasi, konflik dan krisis rasa percaya diri. Selain itu siswa SMP sedang memasuki lingkungan baru, lingkungan yang jauh berbeda dengan sebelumnya yang berpotensi menimbulkan masalah-masalah dalam dirinya termasuk krisis rasa percaya diri. Dampak yang muncul seperti anak tidak mau berangkat sekolah, tidak mau belajar, suka membolos dan pada akhirnya prestasi belajar menurun.

Hal ini dikuatkan dengan pendapatnya Pradipta Sarastika (2014:7) yang mengemukakan bahwa ciri-ciri orang yang tidak percaya diri adalah menghindari kontak mata, tidak mau melakukan apa-apa, terkadang memperlihatkan perilaku mengamuk, dan tidak banyak berbicara. Melihat dampak yang cukup berpengaruh terhadap kehidupan siswa maka rasa percaya diri yang rendah tersebut harus ditingkatkan agar tidak mengganggu anak dalam mencapai perkembangan yang optimal di sekolah. Salah satu cara yang dapat digunakan sebagai usaha meningkatkan 
kepercayaan diri siswa adalah menggunakan bimbingan kelompok. Penggunaan layanan bimbingan kelompok diharapkan tepat memberikan kontribusi terhadap peningkatan kepercayaan diri siswa.

Bimbingan kelompok
mempunyai manfaat besar bagi individu, dengan memanfaatkan dinamika kelompok dapat menggali dan mengembangkan diri dan potensi yang dimiliki individu. Bimbingan kelompok sangat tepat bagi remaja karena memberikan kesempatan untuk menyampaikan gagasan, perasaan, permasalahan, melepas keragu-raguan diri, dan pada kenyataanya mereka akan senang berbagi pengalaman dan keluhan-keluhan pada teman sebayanya. Dalam kegiatan kelompok, anggota kelompok dapat menyadari bahwa dia bukan satu-satunya orang yang memiliki masalah atau kesulitan. Anggota kelopok dapat menyadari pula bahwa kadang-kadang kesulitan orang lain bahkan lebih berat daripada kesulitannya sendiri.

Selama ini bimbingan kelompok memang sudah dilaksanakan di sekolah tetapi masih cenderung untuk membantu siswa yang mempunyai masalah, belum memfokuskan pada masalah-masalah yang bersifat umum seperti masalah krisis kepercayaan diri. Sebagai strategi agar bimbingan kelompok memberikan kontribusi terhadap peningkatan kepercayaan diri perlu memanfaatkan layanan yang lebih bervariasi sesuai kebutuhan dan permasalahannya salah satunya menggunakan metode outbond.

Metode outbond adalah bentuk kegiatan yang dilakukan di luar atau lapangan terbuka. Outbond merupakan kegiatan belajar mandiri yang sangat luas mulai dari mengatasi rasa takut, ketergantungan dan rasa percaya diri sehingga mengenal jati diri dan mau mendengar orang lain (As'adi, 2009 : 23). Metode outbond bertujuan untuk mengembangkan potensi atau pengetahuan dan melatih dalam menyesuaikan diri terhadap perubahan dan perkembangan dari individu menjadi lebih baik dari sebelumnya. Menurut Subagyo (2013) dalam kegiatan outbound training management (OMT), ada beberapa tahapan yang harus dilakukan agar pelatihan outbound training bisa berjalan dengan baik dan sesuai dengan tujuan atau sasaran yang diinginkan. Tahapan tersebut mengacu pada proses pembelajaran efektif yaitu meliputi: (1) pembentukan kelompok, (2) pelaksanaan outbond dengan berbagai macam permainan, (3) de breafing dan (4) evaluasi.

Penelitian ini dimaksudkan untuk memecahkan permasalahan tentang Apakah penggunaan layanan bimbingan kelompok dengan teknik Outbond efektif untuk membantu meningkatkan kepercayaan diri?. Dari hasil penelitian ini diharapkan dapat membentuk rasa percaya diri siswa yang kuat sehingga akan mampu memaksimalkan potensi yang ada di dalam diri siswa. 


\section{METODE PENELITIAN}

Berdasarkan fokus permasalahan dan tujuan penelitian maka penelitian ini menggunakan pendekatan kuantitatif. Populasi penelitian adalah siswa kelas VII SMP Ma'arif Borobudur Kabupaten Magelang Tahun Pelajaran 2017/2018 yang berjumlah 65 siswa yang terdiri dari dua kelas. Teknik pengambilan sampel dengan kombinasi antara quota sampling dan purposive sampling dengan cara memberikan skala likert untuk mengetahui tingkat kepercayaan diri siswa dan diambil 20 siswa yang mendapatkan nilai terendah. Selanjutnya jumlah siswa dibagi menjadi dua kelompok, yaitu kelompok eksperimen dan kelompok kontrol dimana masing-masing kelompok berjumlah 10 siswa. Desain penelitian menggunakan control group pre-test post-test, sedangkan analisis data menggunakan t-test.

\section{HASIL PENELITIAN DAN PEMBAHASAN}

Berdasarkan keterangan dari seluruh sumber data dapat disimpulkan bahwa secara umum program bimbingan kelompok sudah dilaksanakan, namun pelaksanaan bimbingan kelompok masih insidental, hanya menyesuaikan dengan kebutuhan siswa, belum terprogram secara pasti. Setelah mengikuti kegiatan bimbingan kelompok dengan metode outbond siswa merasa senang. Siswa dapat mengutarakan pendapatnya, belajar menghormati dan menghargai orang lain. Berdasarkan hasil analisis skala likert tentang kepercayaan diri terhadap siswa kelas VII SMP Ma'arif Borobudur tahun ajaran 2017/2018 diperoleh hasil bahwa:

1. Deskripsi Data Kepercayaan Diri Pada Kelompok Kontrol

Berdasarkan data pretest dari kelompok kontrol diketahui bahwa siswa yang memiliki kepercayaan diri tinggi sebanyak 1 orang atau $1 \%$, selebihnya ada 9 orang atau $90 \%$. Sedangkan data postest dari kelompok kontrol diketahui bahwa siswa yang memiliki kepercayaan diri tinggi sebanyak 3 orang atau $30 \%$ selebihnya ada 7 orang atau $70 \%$ yang memiliki kepercayaan diri sedang.

2. Deskripsi Data Kepercayaan Diri Pada Kelompok Eksperimen

Berbeda dari data pretest kelompok kontrol, data pretest kelompok eksperimen diperoleh hasil sebagai berikut: 2 orang atau $20 \%$ memiliki kepercayaan diri tinggi dan selebihnya 8 orang atau $80 \%$ memiliki kepercayaan diri tinggi. Selanjutnya untuk data postest diperoleh hasil bahwa semua anggota bimbingan kelompok yang berjumlah 10 orang atau $100 \%$ memiliki kepercayaan diri yang tinggi. Sedangkan berdasarkan rata-rata posttest kelompok eksperimen sebesar 122,7 sedangkan posttest kelompok kontrol sebesar 98,6 
sehingga dinyatakan rata-rata kepercayaan diri siswa kelompok eksperimen lebih besar dibandingkan dengan kelompok kontrol.

Adapun hasil penghitungan uji ttest maka didapat nilai $t_{\text {hitung }}=2,7$. Kemudian nilai $\mathrm{t}$ hitung dikonsultasikan dengan nilai $\mathrm{t}$ tabel. Untuk melihat $\mathrm{t}$ tabel digunakan $\mathrm{dk}=\mathrm{n} 1+\mathrm{n} 2-2$, diperoleh nilai $\mathrm{t}$ tabel yaitu 1,7. Dengan demikian $t_{\text {hitung }}>t_{\text {tabel }}$ sehingga hipotesis Ho ditolak. Penolakan Ho membuktikan bahwa ada perbedaan antara rata-rata tingkat kepercayaan diri siswa dari hasil postest antara kelompok kontrol dan eksperimen sehingga layanan bimbingan kelompok dapat dikatakan efektif untuk meningkatkan kepercayaan diri siswa.

Melalui layanan bimbingan kelompok dengan metode outbond, siswa dapat mengembangkan kepercayaan diri, melatih komunikasi yang efektif, pemecahan masalah, melatih konsentrasi, kejujuran, kerjasama, kepemimpinan, serta mengembangkan inisiatif siswa. Hal ini sesuai dengan hasil penelitian yang dilakukan oleh Imam Subagyo (2013) yang menyatakan bahwa berdasarkan hasil uji lapangan dapat disimpulkan bahwa bimbingan kelompok dengan teknik outbound efektif untuk meningkatkan penyesuaian diri siswa. Layanan bimbingan kelompok dengan metode outbond pada kenyataannya dapat meningkatkan kepercayaan diri siswa melalui permainan-permainan yang menyenangkan dan tidak berisiko besar. Hasil penelitian ini mengukuhkan pandangan mengenai permainan yang disampaikan oleh Respati dan Lengkong (2010: 8) yang menyatakan bahwa "metode pembelajaran melalui lecture saja, walau seringkali sudah dilengkapi dengan audio-visual seperti video sekarang tidak semaksimal dibandingkan dengan yang melibatkan games. Hal ini dilakukan guna membatu siswa mengatasi masalahmasalah yang tengah dihadapi. Jika masalah yang dialami segera diatasi maka dapat menimbulkkan dampak positif bagi keberhasilan siswa dalam menumbuhkan tanggung jawab dan dapat meningkatkan kepercayaan dirinya.

\section{SIMPULAN}

Selama ini program bimbingan kelompok sudah dilaksanakan, namun dalam melaksanaan bimbingan kelompok masih bersifat insidental, hanya menyesuaikan dengan kebutuhan siswa. Adapun tema yang dibahas belum sampai pada masalah kepercayaan diri siswa dan dalam pelaksanaannya masih menggunakan bimbingan kelompok dengan metode konvensional. Berdasarkan rata-rata posttest kelompok eksperimen sebesar 122,7 sedangkan posttest kelompok kontrol sebesar 98,6 sehingga dinyatakan rata-rata kepercayaan diri siswa kelompok eksperimen lebih besar dibandingkan dengan kelompok kontrol. 
Sedangkan berdasarkan hasil penghitungan uji t-test maka didapat nilai $t_{\text {hitung }}=2,7$. Kemudian nilai $t_{\text {hitung }}$ dikonsultasikan dengan nilai $t_{\text {tabel }}$. Untuk melihat $\mathrm{t}_{\text {tabel }}$ digunakan $\mathrm{dk}=$ $n 1+n 2-2$, diperoleh nilai $t_{\text {tabel }}$ yaitu 1,7. Dengan demikian $t_{\text {hitung }}>t_{\text {tabel }}$ sehingga hipotesis Ho ditolak. Penolakan Ho membuktikan bahwa ada perbedaan antara rata-rata tingkat kepercayaan diri siswa dari hasil postest antara kelompok kontrol dan eksperimen sehingga layanan bimbingan kelompok dapat dikatakan efektif untuk meningkatkan kepercayaan diri siswa.

\section{DAFTAR PUSTAKA}

As'adi, M. 2009. Metode Permainan Dalam Pembelajaran. (http: belajarpsikologi.com). Diakses Senin, 1 Mei 2017 jam 13.00 WIB.

Angelis, B.D. 2005. Confidence: Percaya Diri Sumber Sukses dan Kemandirian. Jakarta: PT. Gramedia Pustaka Utama.
Ghufron. 2010. Teori-Teori Perkembangan. Bandung: Refika Aditama.

Nurihsan, A.J. dan Agustin, M. 2011. Dinamika Perkembangan Anak dan Remaja: Tinjauan Psikologi, Pendidikan, dan Bimbingan. Bandung: PT. Refika Aditama.

Pradipta Sarastika. 2014. Buku Pintar Tampil Percaya Diri. Yogyakarta: Araska.

Respati, B.D.N \& Lengkong, P. 2010. Koleksi Games Seru. Yogyakarta: Percetakan Galang Press.

Subagyo, I. 2013. Bimbingan Kelompok Dengan Teknik Outbound Untuk Meningkatkan Penyesuaian Diri Siswa. Jurnal Bimbingan Konseling 2 (2) (2013), http://journal.unnes.ac.id/sju/ind ex.php/jubk. 